P-ISSN: 2615-1723

E-ISSN: 2615-1766

April 2020
Jurnal Riset Pendidikan Dasar

03 (1), (2020) $71-76$

Submitted: Februari, Accepted: Maret, Published: April

\title{
EFEKTIVITAS PENGGUNAAN MEDIA POWER POINT TERHADAP HASIL BELAJAR IPS KELAS V SD 128 TURUNGAN BERU KECAMATAN HERLANG KABUPATEN BULUKUMBA
}

\author{
Nursyaida $^{1^{*}}$, A. Hardiyanti ${ }^{2}$ \\ ${ }^{1,2}$ Program Studi Pendidikan Guru Sekolah Dasar, Fakultas Keguruan dan Ilmu Pendidikan, \\ UniversitasPahuwato Gorontalo, Indonesia
}

Korespondensi. *E-mail: aidanursyaida@unipo.ac.id

\begin{abstract}
Abstrak
Penelitian ini bertujuan untuk (i) mengetahui gambaran penerapan penggunaan media power point dalam pembelajaran IPS Siswa kelas V SD Negeri 128 Turungan Beru Kabupaten Bulukumba; (ii) mengetahui gambaran hasil belajar IPS Siswa kelas V SD Negeri 128 Turungan Beru Kabupaten Bulukumba dalam menggunakan media power point; (iii) mengetahui keefektifan penggunaan media power pointdalam meningkatkan hasil belajar IPS Siswa kelas V Negeri 128 Turungan Beru Kabupaten Bulukumba. Jenis penelitian ini adalah penelitian pre-eksperimen dengan desain one group pre test-post test.Subjek penelitian adalah Siswa kelas V yang berjumlah 41 orang. Teknik pengumpulan data observasi, tes, dan dokumentasi. Data yang diperoleh dianalisis dengan uji normalitas dan uji homogenitas yang menunjukkan bahwa data hasil penelitian berdistribusi normal dan homogen dilanjutkan dengan uji hipotesis menggunakan analisis statistik inferensial (uji-t). Hasil penelitian menunjukkan bahwa (i) penggunaan media power point terhadap hasil belajar Siswa kelas V SD Negeri 128 Turungan Beru Kabupaten Bulukumba berkualifikasi " baik “. (ii) hasil belajar IPS Siswa dengan penggunaan media power point pada kelas V SD Negeri 128 Turungan Beru Kabupaten Bulukumba berkategori "tinggi " dibandingkan dengan hasil belajar yang tidak menggunakan media power point berkategori "rendah" (iii) penggunaan media power point pada pembelajaran IPS Siswa kelas V SD Negeri 128 Turungan Beru Kabuapten Bulukumba efektif dalam meningkatkan hasil belajar IPS Siswa kelas V SD Negeri 128 turungan Beru Kabupaten Bulukumba.
\end{abstract}

Kata Kunci: Efektivitas, Penggunaan Media Power Point, Hasil Belajar IPS

\section{EFFECTIVENESS OF USING POWER POINT MEDIA ON LEARNING RESULTS OF IPS CLASS V SD 128 TURUNGAN BERU SUB-DISTRICT HERLANG BULUKUMBA DISTRICT \\ Abstract}

This study aims to (i) find out the description of the use of power point media in Social Studies learning for Grade V students of SD Negeri 128 TurunganBeru, Bulukumba Regency; (ii) knowing the description of social studies learning outcomes of Grade V students of SD Negeri 128 TurunganBeru in Bulukumba Regency in using power point media. (iii) knowing the effectiveness of using power point media in improving Social Studies learning outcomes of Grade V students of State 128 TurunganBeru, Bulukumba Regency. This type of research is a pre-experimental research design with one group pre-test-post test. The subjects of the study were 41st grade $V$ students. Data collection techniques are observation, test, and documentation. The data obtained were analyzed with the normality test and homogeneity test which showed that the results of the study were normally distributed and homogeneous followed by the hypothesis test using inferential statistical analysis (t-test). The results showed that (i) the use of power point media on the learning outcomes of Grade V students of SD Negeri 128 TurunganBeru in Bulukumba Regency were "good" qualifications. (ii) Social studies learning outcomes of students with the use of power point media in class V SD Negeri 128 TurunganBeru in Bulukumba Regency are categorized as "high" compared to learning outcomes that do not use media power points categorized as "low". (iii) the use of power point media in Social Studies learning for Grade V students of SD Negeri 128 TurunganBeruKabuaptenBulukumba is effective in improving social learning outcomes of Grade V students of SD Negeri 128 TurunganBeru in Bulukumba Regency.

Keywords: Effectiveness, Use of Power Point Media, Social Studies Learning Outcomes 


\section{PENDAHULUAN}

Salah satu faktor yang mempengaruhi menurun/rendahnya hasil belajar siswa disebabkan oleh penggunaan mediadalam penyajian materi yang kurang berpariasi, bahkan pada beberapa sekolah guru tidak menggunakan media dalam pembelajaran, hal ini terlihat dari kecenderungan pengajaran lebih monoton pada metode konvensional, sehingga siswa menjadi bosan dan kurang memahami konsep yang diajarkan.

Dalam proses pembelajaran masih banyak guru yang menggunakan media sederhana yaitu media yang bersumber dari buku , dominasi guru dalam proses pembelajaran menyebabkan siswa lebih bersifat pasif sehingga mereka lebih banyak menunggu sajian guru dari pada mencari dan menemukan sendiri pengetahuan, keterampilan atau sikap yang mereka butuhkan. Dalam tingkatan pendidikan di SD materi yang banyak menekankan aspek berpikir nilai serta berfikir kritis adalah kelas V. Kelas V merupakan materi yang paling sulit dipahami oleh siswa dan fakta tersebut sesuai dengan realita yang ada di lapangan yaitu di SD Negeri 128 Turungan Beru Kecamtan Herlang Kabupaten Bulukumba.Untuk mengatasi permasalahan tersebut, maka solusi yang dipilih oleh peneliti adalah menggunakan metode pembelajaran yang relevan. Salah satunya adalah mengefektifkan penggunaan media pembelajaran sebagai penunjang terciptanya proses belajar yang inovatif, harmonis, dan berkualitas. Dengan media pembelajaran ini diharapkan siswa merasa senang dan antusias selama proses pembelajaran sehingga dapat meningkatkan hasil belajarnya.

\section{METODE}

Penelitian ini merupakan penelitian kuantitatif desain pre-eksperimen dengan model pendekatan pre-test and post-test one group design yaitu eksperimen yang dilakukan pada satu kelompok tanpa kelompok pembanding.

jenis penelitian ini adalah PreExsperiment Design dengan desain penelitian yang digunakan adalah One Group Pre test-post test.

Gambar pra eksperimen model pre-test post-test one group design

$$
\mathrm{O}_{1} \mathrm{X} \mathrm{O}_{2}
$$

Gambar 1 Desain Penelitian

Keterangan :

$\mathrm{O}_{1} \quad$ :Pretest hasil belajar IPS

$\mathrm{X}$ :Penerapan Medial pembelajaran Power Point

O2 : Posttest hasil belajar IPS

Subjek dalam penelitian ini adalah kelas V SD Negeri 128 Turungan Beru Kecamatan Herlang kabupaten Bulukumba yang berjumlah 41 Siswa.

Teknik analisis data yang digunakan dalam penelitian ini yakni analisis statistik deskriptif dan analisis statistik inferensial. Data yang dianalisis adalah keterlaksanaan pengunaan media Power Point dalam pembelajaran dan hasil belajar siswa yang diperoleh dari hasil belajar melalui pretest dan posttest dengan melihat peningkatan nilai.

Analisis deskriptif digunakan untuk menganalisis data hasil belajar siswa. Analisis deskriptif bertujuan untuk melihat gambaran data secara umum.

Analisis tes hasil belajar diarahkan pada pencapaian hasil belajar individu dan klasikal. Setiap siswa dinyatakan berhasil secara individu jika memperoleh nilai minima 170 (KKM yang harus dicapai dikelas V SDN 128 Turungan Beru pada mata pelajaran IPS) dan tuntas secara klasikal minimal $85 \%$.

Tabel 1 Pedoman Pengkategorian Hasil Belajar

\begin{tabular}{cc}
\hline Nilai & Kategori \\
\hline $86-100$ & Sangat baik \\
\hline
\end{tabular}

Copyright $@ 2020$, JRPD, ISSN 2615 - 1723 (Print), ISSN 2615 - 1766 (Online) 
Jurnal Riset Pendidikan Dasar, 03 (1), April 2020 (71-76)

Nursyaida, A.Hardiyanti

\begin{tabular}{cc}
\hline $71-85$ & Baik \\
\hline $55-70$ & Cukup \\
\hline $40-54$ & Kurang \\
\hline $0-39$ & Sangat kurang \\
\hline
\end{tabular}

Sebelum melakukan analisis tersebut terlebih dahulu melakukan uji prasayarat statistik parametrik, yang meliputi:

a. Uji normalitas menggunakan One-Sample Kolmogorov - Smirnov Test dibantu dengan software SPSS 16,0 for windows dan data hasil belajar dari sampel akan berdistribusi normal dengan kriteriasig $>\alpha$ dengan taraf $\alpha$ $=0,05$.

b. Uji homogenitas menggunakan Levene's Testfor Equality of Variances dibantu dengan software SPSS 16,0 for windows dan kriteria pengujian yang digunakan adalah sig $>\alpha$ dengan taraf $\alpha=0,05$.

Kriteria yang digunakan untuk menentukan tingkat pencapaian ketuntasan hasil belajar siswa adalah Kriteria Ketuntasan Minimal (KKM) yang berlaku di SDN 128 Turugan Beru Kecamatan Herlang Kabupaten Bulukumba adalah.

1. Nilai $70-100$ dikategorikan tuntas

2. Nilai 0 - 69 dikategorikan tidak tuntas

\section{Pengujian Hipotesis Penelitian}

Setelah dilakukan uji normalitas, selanjutnya dilakukan pengujian hipotesis dengan menggunakan uji kesamaan rata-rata yaitu dengan menerapkan teknik uji-t berpasangan.

Secara statistika, hipotesis ini dirumuskan sebagai berikut :

$\mathrm{H}_{\mathrm{o}}$ versus $\mathrm{H}_{1}$

1) $\mathrm{H}_{0:} \quad \mathrm{P} \geq 0,05$ (Tidakada perbedaan nilai Hasil Belajar pada pembelajaran IPS siswa kelas V SD Negeri 128 Turungan Beru Kabupaten Bulukumba yang diajar dengan menggunakan media Power Point dan yang tidak menggunakan media Power Point).

$\mathrm{H}_{1:} \mathrm{P}<0,05$ ( ada perbedaan nilai Hasil Belajar pada pembelajaran IPS siswa kelas V SD Negeri 128 Turungan Beru Kabupaten Bulukumba yang diajar dengan menggunakan media Power Point dan yang tidak menggunakan media Power Point).

\section{HASIL DAN PEMBAHASAN}

\section{Gambaran Penggunaan Media Power Point Siswa Kelas V SD}

Bagian ini membahas hasil penelitian tentang gambaran penggunaan media Power Point terhadap hasil belajar IPS pada siswa kelas V SD Negeri 128 Turungan Beru. Berdasarkan hasil analisis data melalui tes Pilihan Ganda, telah ditemukan bahwa terjadi perbedaan hasil belajar IPS kelas V. Berdasarkan hasil penelitian ini pada nilai posttest hasil belajar kecenderungannya berada pada kategori tinggi dan pada nilai Pretest berada pada kategori rendah. Dari hasil data tersebut menunjukkan adanya perbedaan nilai hasil belajar siswa dalam pembelajaran IPS.

Adanya perbedaan nilai hasil belajar siswa dalam pembelajaran IPS yang diajar dengan penggunaan media Power Point dan yang diajar tanpa penggunaan media Power Point adala hakibat adanya perbedaan aktivitas siswa selama proses pembelajaran. Sebagaimana diketahui bahwa pengguanaan media Power Point dapat membantu siswa dalam mengembangkan daya kreativitasnya, karena siswa pada usia sekolah dasar memiliki Stimulus yang kuat, ketika ditampilkan halhal yang menarik .Sebagaimana menurut teori yang ada yaitu Dale dalam Arsyad (2013:13) memperkirakan bahwa pemerolehan hasil belajar melalui indera pandang berkisar $75 \%$, melalui indera dengar sekitar 13\%, dan melalui indera lainnya sekitar 12\%. Salah satu landasan teori yang sering digunakan adalah teori dari Dale yaitu Dale's Cone of Experience (kerucut pengalaman Dale).Menurut Arsyad (2013: 89) media pembelajaran artinya semua alat peraga yang digunakan dalam proses belajar yang bisa dinikmati lewat panca-indera. Media pembelajaran memegang peran yang sangat penting dalam proses belajar. Media dapat memperlancar pemahaman dan memperkuat ingatan.Visual dapat pula

Copyright C2020, JRPD, ISSN 2615 - 1723 (Print), ISSN 2615 - 1766 (Online) 
menumbuhkan minat siswa dan dapat memberikan hubungan antara isi materi pelajaran dengan dunia nyata. Melalui tahapan ini siswa aktif dalam kegiatan pembelajaran sesuai dengan langkah-langkah penggunaan media Power Point dalam pembelajaran IPS.

\section{Gambaran Hasil Belajar IPS Siswa}

Hasil analisis data menunjukkan bahwa rata-rata hasil belajar siswa yang diperoleh melalui tes akhir setelah pembelajaran IPS dengan penggunaan media pembelajaran Power Point yaitu berada pada kategori sangat tinggi. Jika merujuk pada kriteria yang ditetapkan pada bab III maka dapat dikemukan bahwa hasil belajar siswa tuntas secara klasikal. Hasil yang disajikan di atas sejalan dengan yang dikemukakan oleh Johnson \& Johnson (Trianto, 2010: 57) menyatakan bahwa tujuan pokok belajar kooperatif adalah memaksimalkan belajar siswa untuk peningkatan prestasi akademik dan pemahaman baik secara individu maupun secara kelompok.

Pada tabel distribusi frekuensi dan persentase hasil belajar siswa melalui media pembelajaran Power Point menunjukkan bahwa frekuensi siswa yang berada pada kategori sangat tinggi sebanyak 26 orang siswa dan kategori tinggi sebanyak 15 orang siswa. Dari hasil ini dapat dilihat bahwa pada pembelajaran IPS melalui media pembelajaran Power Point pada siswa kelas V SDN 128 Turungan Beru dapat meningkatkan hasil belajar siswa secara klasikal.

Data tentang perolehan hasil belajar siswa sebelum dan setelah diterapkan media pembelajaran Power Point dapat dilihat dengan menggunakan hasil belajar siswa pada pembelajaran menunjukkan besarnya peningkatan nilai hasil belajar siswa sebelum dan sesudah diterapkan media pembelajaran Power Point. Hasil yang diperoleh untuk media pembelajaran Power Point adalah 34 orang siswa mengalami peningkatan pada kategori sangat rendah kemudian mengalami peningkatan hasil belajar setelah penerapan media pembelajaran Power Point dengan persentase tinggi.

\section{Efektivitas Penggunaan Media Power Point Terhadap hasil Belajar IPS Siswa}

Bagian ini membahas analisis data penelitian tentang Efektivitas Pengggunaan Media Power Point terhadap hasil Belajar IPS Kelas V SDN 128 Turungan Beru Kecamatan herlang Kabupaten Bulukumba. Dengan penggunaan media power Point terhadap hasil belajar IPS Kelas V SD, siswa difasilitasi oleh guru untuk lebih diberdayakan dan berperan aktif dalam menemukan sendiri pengetahuannya berkaitan dengan materi yang dipelajarinya. Dalam pembelajaran selama pelaksanaan penelitian Observer mengajar siswa dengan menerapkan apa yang telah tertuang secara konsep dalam Rencana Pelaksanaan Pembelajaran (RPP), dilaksanakan sepenuhnya dalam pembelajaran yaitu sesuai dengan langkah-langkah pelaksanaan penggunaan media Power Pointdalam pembelajaran IPS.

Penelitian yang dilakukan dapat membuktikan bahwa penggunaan media Power Point Efektif terhadap Hasil Belajar IPS Kelas V. Hal tersebut dikarenakan kesesuaia prosedur pelaksanaan mulai dari perencanaan dan pelaksanaan penelitian. Hal ini sejalan dengan penelitian relevan yang dilakukan oleh Supriyatno (2012) dengan judul " pengaruh penggunaan media Power Point terhadap hasil belajar IPA Siswa KelasVSDN lanjan kecamatan Sumowono Kabupaten Semarang. Hasil penelitian menunjukkan bahwa penggunaan media power point berpengaruh terhadap hasil belajar siswa pada mata pelajaran IPA siswa Kelas V SD N lanjan kecamatan Sumowono Kabupaten Semarang semester Genap tahun $2011 / 2012$.

Pada proses perencanaan Pembelajaran IPS dengan menggunakan media Power Point tentunya dapat membuat siswa belajar secara efektif. Berdasarkan hasil penelitian tersebut maka dapat disimpulkan bahwa Pengggunaan Media Power Point Efektif terhadap hasil Belajar IPS Siswa kelas V SD Negeri 128

Copyright (C2020, JRPD, ISSN 2615 - 1723 (Print), ISSN 2615 - 1766 (Online) 


\section{Jurnal Riset Pendidikan Dasar, 03 (1), April 2020 (71-76)}

Nursyaida, A.Hardiyanti

Turungan Beru Kecamatan Herlang Kabupaten Bulukumba.

\section{SIMPULAN}

Berdasarkan hasil penelitian yang telah dilakukan tentang Efektivitas penggunaan media gambar terhadap hasil belajar IPS kelas V SD Negeri 128 Turungan Beru kecamatan Herlang kabupaten Bulukumba, dapat ditarik kesimpulan sebagai berikut:

1. Gambaran Penggunaan media Power Point berkategori "baik".

2. Nilai rata-rata Hasil Belajar IPS siswa kelas V SD Negeri 128 Turungan Berulebih tinggi berkategori "Tinggi" daripada hasil belajar IPS Siswa Kelas V yang tidak menggunakan media Power Point berkategori "Rendah"

3. Penggunaan media Power Point dalam pembelajaran IPSEfektif dalam meningkatkan Hasil Belajar Siswa kelas V SD Negeri 128 Turungan Beru Kecamatan Herlang Kabupaten Bulukumba.

Berdasarkan hasil penelitian yang telah dilakukan diperoleh hasil bahwa penggunaan media power point dalam pembelajaran IPS berpengaruh terhadap hasil belajar IPS Siswakelas V SD Negeri 128 Turungan Beru, maka dapat diajukan saran-saran yang perlu dipertimbangkan bagi semua pihak yang berkepentingan terkait hasil penelitian adalah sebagai berikut:

1. Bagi para guru, penggunaan media Power Point dalam pembelajaran IPS dapat dipilih sebagai salah satu media pembelajaran yang dapat diterapkan untuk meningkatkan hasil belajar siswa. Sebaiknya guru juga sebagai inspirator bagi siswa khususnya dalam pembelajaran.

2. Bagi Sekolah atau Lembaga Pendidikan, agar dapat memberikan mediasi perkembangan kompetensi guru melalui kegiatan, penelitian dan pendidikan/pelatihan khususnya dalam hal penggunaan media Power Point untuk meningkatkan hasil belajar siswa dalam pembelajaran IPS

3. Bagi peneliti selanjutnya, hasil penelitian ini dapat dijadikan salah satu dasar dalam mengambil keputusan dalam peningkatan hasil belajar siswa dalam pembelajaran IPS khususnya dalam kegiatan pembelajaran sehari-hari di sekolah dan dilakukan dalam jangka panjang dan berkelanjutan sehingga menjadi suatu kebiasan dalam proses pembelajaran.

\section{DAFTAR PUSTAKA}

Andariana, A. (2014). "Pengaruh Model Pembelajaran Based Learning (PBL) terhadap Hasil Belajar Kognitif, Afektif, dan Psikomotor Siswa Kelas XI SMA Negeri I Tellusiattinge. Tesis. Tidak diterbitkan. Universitas Negeri Makassar.

Arsyad,, A. (2013). Media Pembelajaran. Jakarta; Raja GrafindoPersada

Bungin, Burhan. (2004). Metode Penelitian Kuantitatif. Surabaya: Kencana Prenada Media Group.

Sardiman, A.M. (1996). Interaksi dan Motivasi Belajar dan Mengajar.Jakarta: Grasindo.

Setyawan, B. (2006). Pengaruh Media Power Point Terhadap Peningkatan Prestasi Belajar Biologi Siswa Kelas IX SMP Negeri 39 Surabaya. E-Jurnal Dinas Pendidikan Kota Surabaya. Vol 4. PP 2337-3253.

Slameto. (1995). Proses Belajar Pembelajaran. Bandung: Kencana.

Srimaya. (2012). Efektivitas Media Pembelajaran Power Point untuk Meningkatkan Motivasi dan Hasil Belajar Biologi Siswa Kelas XI IPA 3 SMAN Pangkajene. Tesis. Tidak diterbitkan. Universitas Negeri Makassar.

Sudiman, A.S. (2012). Media Pendidikan Pengertian, Pengembangan, dan 
Jurnal Riset Pendidikan Dasar, 03 (1), April 2020 (71-76)

Nursyaida, A.Hardiyanti

Pemanfaatannya. Jakarta: Raja Grafindo Persada.

Sudjana, N. (2013). Dasar-dasar Proses Belajar Mengajar. Bnadung: Sinar Baru Algensindo.

Sugiono. (2013). Metode Penelitian Pendidikan. Bandung: Alfabeta.

Suprijono, Agus. 2013. Cooperative Learning. Yogyakarta; PustakaBelajar.

Susanto, A. (2013). Teori Belajar \& Pembelajaran di Sekolah Dasar. Jakarta: Kencana Prenada Group

Kustandi., \& Sutjipto. (2011). Media Pembelajaran. Bogor:Ghalia Indonesia.

Marissa. (2011). Komputer dan Media Pembelajaran. Jakarta: Universitas Terbuka 